\title{
Building Entrepreneurship Environment For Students Through Balinese Speaking Skills
}

\author{
Suardiana I Wayan \\ Faculty of Cultural Sciences, Udayana University \\ e-mail: i.suardiana@yahoo.co.id
}

\begin{abstract}
Efforts to innovate in language care is done by developing a model of skills that can be used as a provision of life by the speaker. Balinese language skills that will be offered in oral level such as mapidarta art (speech / orator), become ugrawakya/MC (Master of Ceremony), madarmawacana art (sermon), art of masatua (telling) Bali, as broadcaster (radio and TV); in the level of writing covers the art of writing opinion, writing reportoar in relation as a journalist. In this study only disclosed about the guide (model) of art into ugrawakya/MC (Master of Ceremony). This research data is a qualitative data that is extracted from the relevant books to guide or direct someone to be able to become a ugrawakya (MC) well. Methods of data collection is done by library study assisted by the technique of record. Data were analyzed by analytic descriptive method with deductive-inductive technique, and presented by informal method.
\end{abstract}

Keywords: Language skills, students, ugrawakya (MC), and entrepreneurship.

\section{INTRODUCTION}

The research entitled "Building Entrepreneurship Souls in Students through Balinese Speaking Skills" aims to explore and foster the spirit of entrepreneurship for students of Bali Literature Program, Faculty of Cultural Sciences, Udayana University in particular and the younger generation of Bali in general in the field of Balinese language skills. Nida (1957: 19) pointed out that the components of language skills have four parts, namely: (a) listening skills; (b) speaking skills; (c) reading skills; and (d) writing skills. Of the four language skills will be made a guide to be entrepreneurs for students in Prodi Sastra Bali, Faculty of Cultural Sciences, Unud especially after they finish the study able to answer the challenges of the world of work.

The model is a guide that will be divided into two parts: first describes the techniques and procedures in organizing the event or in the language of Bali called ugra wakya (reader/MC), masatua (telling) Bali, mapidato technique (speech) and madharma wacana (sermon). In the second part (the level of writing) will be presented a guide model on writing literature and writing on mass media (newspaper/magazine) in Bali. In the first stage it belongs to the speaking skill, while in the second stage is the writing skill. This sequence is based on the advice of Sukirno (2010: 9 - 10) who says, "... ketrampilan menulis merupakan ketrampilan yang paling sulit untuk dilakukan oleh manusia", so in this study done later to organize the mindset of students.

Writing skills will not come automatically, but should be through practice and practice on a regular and ongoing basis. More to write in Latin with Balinese language that has been rarely done among the younger generation of Bali and even academics (read: students and lecturers). Therefore, in this period, this research tries to give guidance to students and society in Bali, especially in speaking level with Balinese language, that is technique as ugrawakya (MC) as a means of searching life skill. The model or reference that we will offer to students in Balinese Literature, Faculty of of Cultural Sciences, Udayana University and the public speaking the mother language of Bali, especially among the younger generation in order to be able to become ugrawakya (the host) well.

The Balinese language has been getting offortunity from Balinese policy makers in recent years. The government's attention to Balinese language does not necessarily make its speakers rise from adversity. In fact, many problems arise that must be addressed immediately. This has been the result, Mother's language for Balinese people almost forty years since the 1970s experienced 'blood deprivation'. It is said to be lethargic, because the Balinese language is not taught in formal education on an ongoing basis and on the other hand Balinese language is abandoned by its speakers because it does not promise financially to its learners.

As a concrete manifestation that the government is concerned with the Balinese language, since 2016 the Bali Provincial Government has raised the Bali Language Extension Contractors who are deployed in all of the existing Bali Provinces of 716 (Suardiana, 2016: 4). Meanwhile, in the same year Badung Regency (2016) promised to the younger generation of Bali who have a teacher certificate, will be appointed to fill the formation at the level of Primary and Secondary Education (Bali Post, 24 August 2016 p.2). Furthermore, in the same daily also followed by Karangasem Regency and Denpasar City Departement promise the same thing for Balinese language assumption. 
The possibility of appointment of Balinese Language and Literature graduates to fill the extension contractor and as a teacher like that is not without problems. The problem actually occurs on the quality of Human Resources (HR) graduate Language and Literature Bali itself. Evidently, after the Tenaga Pembrakkan Bali Language Workers for six months (July-December 2016) was at the beginning of the first contract in 2017 as many as 50 people non permanent job (Tenaga Kontrak) Bali Language was resigned. One of the reasons why they are sad is that they are not skilled in Balinese language, especially when they are given the task of training elementary, junior high school and high school students in Balinese language (masatua), giving speeches, hosting (ugra wakya, MC), and other language skills. This is in line with Tarigan's (1986: 1) view, which says, to practice language skills also means to practice thinking skills. For this reason, this research is done to help the graduates of Balinese Departement and the public in pursue Balinese language skills so that after they plunge to the society ready to accept the challenge of work.

\section{DISCUSSION}

\subsection{Term Limitations}

The MC (Master of Ceremonies) in Indonesian is paired with the Event Organizer (Sugono, 2005: 5), while in Bali it is called ugra wakya or Pangénter Baos. As a profession, the role of MC is central to the success of an event, because, as a stylists, the event will be able to run well if the MC can organize the event nicely besides the arrangement of events that are also traced to the main event. Hence the importance of the role of an MC in an event then the MC profession has the value of useful in terms of personal and economic value in this life. Personally, a good MC will be able to lift his or her self-esteem and selfesteem more than others in the environment he is in, while in terms of economic value, the MC profession promises a good income also for the bearer.

When traced further, the history of the MC is actually the same length as the history of human civilization, because in order to get to the society that sustainable and cultured that MC profession is alleged to appear. The presence of MC can also be aligned with the art of speech which is one of the art of speaking to influence audiences. Because, as an art of speech, the MC profession also deals with three main points as processed materials, such as: (1) self-expression related to thoughts, sparks of feeling, will, ideals, fantasies and imagination; (2) knowledge and experience, whether self-owned or the property of others; and (3) the surrounding environment and the universe. The elements of these three sources are processed into speech and then passed on to others with various labels, such as jokes, fairy tales, lectures, speeches, sermons, drama, poetry, prose and so on (Oka 1990: 1).

As an oral language, the art of speech (also MC) in the history of mankind can be noted how effective the art of oral presentation, which can change the history of mankind or the history of a nation. Hitler with his skill in speaking or giving speeches dragged his people into the flames of war with other nations, and caused great misery to mankind (Keraf, 1984: 314). But besides, it can also be noted the influence of important figures who are able to bring peace and prosperity of mankind thanks to their speaking skill. Such figures as Mahatma Gandhi from India and also Bung Karno who was able to deliver the nation of Indonesia to the gates of independence in 1945.

As a profession of 'siblings' with art of speech, MC both use speech as the delivery tool. The difference, the MC first present in an event because he as an opening, because, before someone speech is certainly someone who invited someone to make a speech. The one who invited it was the MC. Thus, the MC comes first and, of course, he first understands something that an orator will talk about or at least an MC can grasp the intent of an orator before he performs his lecture. Therefore, it could be the knowledge, experience, and understanding of a MC needed better than the knowledge and understanding of the orator earlier.

Thus someone who lives by choosing a profession as an $\mathrm{MC}$ is required to have more knowledge of the person or event he or she is organizing. In addition to the opening act, $\mathrm{MC}$ also has an obligation as closing of an event.

\subsection{Conditions to be a Professional MC}

All areas of life that demand maximum results would require conditions. Requirements are needed so that we can measure the ability of each self so as to position ourselves against others, especially if we are interested in developing the profession as an MC. MC is good if has the following conditions:

(a) Extensive knowledge and experience

As already mentioned above that the knowledge and experience of an $\mathrm{MC}$ is very decisive success in delivering an event. Because, without extensive knowledge and experience, it is impossible for an MC to master the situation he faces in a short time, especially without adequate preparation. Having sufficient knowledge and life experience will form understanding attitudes to the community, and be able to appreciate and tolerate the vibrations that live around it. With the depth of knowledge concerning the living fair and the values adopted by society, a person MC can easily master his audience. Because the vast experience will be a source of creativity that is very effective in accordance with the demands of the situation.

(b) Smart

A smart MC will not run out of reason to be creative so the show he delivered will be interesting because of the breadth of his knowledge and experience. Intelligent MCs will be evident from the way things are delivered compared to the MCs that are simply brilliant on the surface that rely on beautiful faces, good sounds, but no creativity and appreciation in appearance. The intelligence can be seen from the ability of an MC to make decisions, make the message clearly, briefly, calmly when things suddenly have to be delivered.

\section{(c) Sense of humor}

In a large-scale event and formal, basically the audience wants an event other than the others. The atmosphere will be different if the MC is able to melt the atmosphere by 
presenting jokes that match the theme of the event, not just imitate the jokes that have been there before. The saturation of the participants will be lost if the MC can insert fresh humor in the midst of an ongoing event, the more the humor is the contemporary joke.

\section{(d) Forbearance}

The patience of an $\mathrm{MC}$ is required when repeated events change. This happens because an event generally involves many parties who each have their own ways and desires in achieving its goals. As a result, when the event is in progress there may be confusing instructions. Faced with such a difficult situation, patience coupled with intelligence is needed by an MC.

\section{(e) Imagination}

A variety of events will be encountered by an MC throughout his career path and each of these events has different characters and difficulty levels. At certain moments the $\mathrm{MC}$ is required to be creative, so that the mediocre event can become more lively, vibrant, and impressive. For that an $\mathrm{MC}$ is required ability to be able to 'embellish' the show and play its role well, by involving the emotions of his audience. That can be realized, if an MC able to issue bright ideas that can only come to those who have high imagination.

An MC can create an atmosphere in accordance with his imagination, but not infrequently also $\mathrm{MC}$ should be able to muffle the emotions of his audience, by receiving imagination owned his own audience. Because, a good MC if it can cultivate a deep impression on his audience after the event ended. The seemingly mediocre event will be festive due to a reliable MC improvising. Therefore, he must often train himself, train his imagination, so that at certain moments in urgent circumstances his imagination arises spontaneously and produces brilliant ideas to cope with the situation.

(f) Enthusiasm

All work will be done well if there is a mood or excitement to do it. An MC will not be able to perform its duties properly if it does not have enthusiasm. Because, according to Larry King enthusiasm will produce a special pleasure for a speaker (MC) and will determine its success (2005: 52 - 53). If without excitement in carrying out the task, an MC will fail to perform its role. The enthusiasm of an MC in delivering an event will be felt by the audience and will automatically affect them. Enthusiasm will reflect the seriousness of $\mathrm{MC}$ in communicating that occurs between the MC and his audience. Enthusiasm it should also be based on the background of the delivered event. Make no mistake putting enthusiasm at opposite event positions; happy events delivered with lackluster passion, otherwise melankolic event delivered with festival.

Events are considered a failure simply because the MC is not able to turn the mood. Such circumstances should be avoided. Do not let the appearance of MC actually lower the mood of the audience. Do not let the appearance of the $\mathrm{MC}$ to be anticlimactic from the overall graph of the event that is expected to reach the climax at the end of the event. (g) Humble and friendly
MC who is able to deliver an event with good name will rapidly skyrocket. His fame is similar to the artist even parallel to the public officials. Therefore, in maintaining the image, as an MC does not quickly arrogant with big names. Because, the arrogance will be reflected on the appearance, through posture and also the words he chose when communicating with his audience. Humility makes the appearance of the MC into a friendly, candid, bright-faced, and ready-to-talk dialogue like a best friend.

The famous MC will enter all segments of society so it must always not dissolve itself with the 'above' environment alone if its presence long wanted to be accepted in the hearts of the wider community.

(h) Ability to cooperate

As the organizer of an event, MC certainly can not work without cooperating with others. Parties are generally associated with the tasks of his profession, such as: protocol, stage manager, soundman, lightingman, and so on. The successful task of an MC, not entirely a personal success, but a team success. Therefore, it takes the ability to work together and a good understanding among fellow officers.

In an event, the most important principle should be applied: The Master of Ceremony (MC) or the Host is an important part of an event and not a spectacle or entertainment!

\subsection{Preparations as MC}

The profession as MC (Master of Ceremonies) as his professional name, is required to be a master for the event he guides. Mention as a master is carried by an MC because of his involvement to perfect the organization of the event becomes the main task. An MC not only takes from one event to another, but he plays a direct role in creating the atmosphere as the characteristics of the show. Because, an event is generally carried out with a particular mission and each has its own character, both in the content of the event and the atmosphere that wants to create. For that, before starting the task as an MC, a professional MC must find out or make an analysis on the show he will bring!

Lies Aryati (2008: 35), an announcer and also a famous $\mathrm{MC}$ in his day gave four tips for an MC before he guided or delivered an event. The four tips are the following questions: (a) What is the show ?; (b) Who is the audience ?; (c) Where is the location ?; and (d) What are its features?

\section{Event Type}

An event will determine the type of event, organizer, characteristics, and how to bring it. Therefore, a professional MC when accepting an offer guides the event, must first understand the event to be guided. Because, knowing the event will be guided will make it easier for an MC to prepare themselves. There are four types of events that generally require the services of an $\mathrm{MC}$, namely:
A. Official events;
B. Semi entertainment events;
C. Entertainment events; and
D. Events of exhibitions.
A. Official Events, including: 
(i) Official / state event, for example: official inauguration, handover of office, award of awards, signing of cooperation agreement (MOU);

(ii) Official ceremonies, such as: National Solidarity Day ceremony, August 17th ceremony, Opening ceremony of PON;

(iii) Inauguration ceremony, for example: the inauguration of the building, the inauguration of the overpass, the inauguration of the factory, the inauguration of the company, the organization, etc.

> Characteristics of official events are: formal, serious, and solemn.

B. Semi Entertainment Event, consisting of:

(i) Company events (HUT), generally held only for internal company (employees) or also for corporate external (corporate clients);

(ii) Lounching event, for the business, launching is usually the introduction of prime products, such as book launches, movies, cars, etc .;

(iii) The breaking event is a farewell event for officials to be transferred or retired within a company. The event is also utilized by the company to introduce new officials who replace previous officials;

(iv) Wedding events. This wedding event was put into a kind of semi-entertainment event because the characteristics of the show is a blend of solemn and rousing. In addition, the arrangement of events is also different or adjust to the circumstances.

$>$ Characteristics of semi-entertainment events is a mix between the formal nature of the official event and the festive nature of entertainment events.

C. Entertainment Events, such as:

(i) Variety show, which is usually a regular gathering event by inviting the audience to enjoy the show. Events like this include the commemoration of August 17, 1945, New Year's Eve, Evening Art, etc.;

(ii) Award presentation. The event is organized by inviting certain circles involved in the assessment to gain awards and related people in the assessment. The event includes: Indonesian Film Festival, Bali TV Award, etc ;

(iii) The event of the competition festival. This event is an event for the participants who follow the contest, such as; race kite competition, kebyar kebong competition, the selection of radio and tv stars (BRTV), festivals of popular songs, and so on.

$>$ The characteristics of this event are festive, passionate, and emotional.

D. Exhibition Events, including:

(i) Exhibitions, such as; exhibition painting, photo, furniture, electronics, etc.,

(ii) Seminars, for example; congresses, deliberations, symposia.

$>$ The characteristic of this event is serious but relaxed, according to the object on display or in accordance with the theme of the seminar.

\section{Audience}

The next step that must be known by an MC after knowing the type of event and the frame of the show is who the audience of the event will be delivered. Understand and understand who the audience will be faced in delivering an event, for an MC is a very decisive success in carrying out the task. Because by knowing the background of the listener it will be easy for the MC to choose the vocabulary (language use) and the attitude taking in the event. Without understanding the background of the participants in an event, the possibility of an MC will not fit in choosing the vocabulary in delivering the show. The language for officials or government officials, for example, will certainly be different from the language of the community with the background of farmers. Therefore, the accuracy in selecting and using the terms appropriate to the background of the audience is also determining the success of an $\mathrm{MC}$ in guiding an event.

Understanding of the background of an audience for an MC will determine its success in 'controlling' situations that are likely to be faced, especially since the guided event was attended by a considerable number of masses.

The characteristics of the audience are distinguished in:

A. Nature of group (maximum 50 people)

(1) Individual

(2) Rationale

(3) Responsive

(4) Critical

B. The nature of the period (unlimited)

(1) The nature of individual melting becomes the nature of togetherness

(2) Emotional

(3) Faded Norms

(4) Easy to influence

(5) Sensitive

\section{Location}

The introduction of the location of an event required by someone who works as an MC solely related to the use of vocals, improvisation, and also clothing that must be prepared. When the event takes place inside a comfortable meeting hall, like a hotel for example, a vocal used by an MC will be very different when compared to an outdoor event. Meetings that take place in a special meeting hall with adequate equipment and a comfortable atmosphere will make the audience more solicitous to attend the event. Such an atmosphere there is very little chance of outside interference that can distract them. In such conditions the MC is free to improvise, no need to increase the volume and sound power.

Something that should be of particular concern to an MC to appear professional is when the event takes place in an open field. An open-air event requires a brief and clear talk, not long-winded, with more serious vocal formation. This is necessary because most likely the sound will break and sometimes disappear due to the wind. 


\section{Events Features}

Understanding the privilege of an event that will be guided for an MC will determine the accuracy in choosing clothes or accessories and how to bring the event. MCs who do not adapt her clothes to the show she's playing will cause her to lose shape or become alien in her own show. It takes a high flexibility of an MC to be able to adapt to different environments and situations. There is a possibility that the event will be held in different customs with the customs of the MC.

The mistake of choosing a costume by an MC will affect the attitude of the MC in bringing an event, which then also will be influential in establishing the atmosphere. Therefore, the appearance in the world of the show is very decisive image for someone who acts the World Carr.

2.4 Event Implementation Technique

There are four techniques that must be cultivated for an MC in the implementation of an event. The professional attitude of an MC is reflected in his mastery of the following techniques.

(a) Sound and speech

(b) Language used

(c) Body language

(d) Appearance

A. Voice and How to Speak

The formation of voice and speech is very important for the person working in the field of oral communication. Sound is the most vital weapon and communication tool for an $\mathrm{MC}$, remembering with a good voice $\mathrm{MC}$ can influence his audience. Although a person's voice is not good, but does not reduce its role in this one area. There are several things that are important to do so that the weakness of the vocal sound can be covered while performing the task as an MC. Such things as speech, volume, power, tone, timbre, breath, speech, intonation, articulation, stressing, and phrasing (beheading a sentence or pause).

\section{B. Language Used}

Language is a medium of oral and written communication and also as a means of expressing ideas. In daily implementation, language is strongly influenced by the language style and dialect of the speaker.

In the world of MCs, especially for official occasions, the dialect is very taboo to be raised by an $\mathrm{MC}$, except on occasions that want to highlight regional elements. Language (Indonesia, Bali) used in the implementation of MC work on official events is a good and correct Indonesian language, polite, and communicative. The selected words should belong to the elements: Ordinary sentences (sentences that refer to daily conversation); Beauty sentences (sentences by using beautiful words to give emotional touch (touch of emotion) to the audience); Hopes sentences; and Heroic sentences (sentences that can evoke audience emotions).

\section{Body Language}

In the world of $\mathrm{MC}$, body language has a role that is not less important with the mastery of language. Because, every move an MC - especially on entertainment or semi entertainment - is a form of acting. In the event, MC must seize first impressions (first impressions) for his audience to perform well. All that impression can be seen through the behavior, facial expressions, and eye contact. From the expression will be seen an MC including a person who is fun, intelligent, friendly, and warm, or a proud person, bodo and superficial.

D. Appearance

Appearance in the world of MC includes dress and makeup. Since the MC in one event is part of an event other than the spectacle, then MC must be a solid harmonization between the organization and the characteristic of the event.

\section{TIPS FOR GUIDING EVENTS WITH ENCHANTING}

1. Unpack the event summary

Outlining the overall event summary to the audience will add value because participants will indirectly be able to know the events they participated in during the event.

2. Eye contact

In order not to appear awkward and disrespectful to the audience, the MC must seek eye contact with the participants. Example: at the mention of the VIP guest, the officer's view so that the impression MC appear to recognize and give special respect to him. If you do not know which VIP guests are, slowly brush eyes into the front row.

3. Opening touch

Opening touch is the effort of an MC to break the ice in an event with steps to pull out interesting jokes, make light inquiries, and can also make controversial questions to participants.

4. Emotional content

In guiding the event, $\mathrm{MC}$ is obliged to create an atmosphere of togetherness and dialogue. For that, it takes the ability to bring controlled emotions that are the binding force between the MC with his audience so that the conversation is more interesting. Therefore an $\mathrm{MC}$ is expected to present emotionally speaking conversations, with the following steps.
(a) reinforce the word
(b) repeating the word
(c) delay the word
(d) extend the word.

\section{CONCLUSION}

Profession ugra wakyal pangénter baos or MC (event organizer) is a skill that requires high skills because the success of an event is determined by the expertise of an ugra wakya (MC) organize the event. Because the presence of ugra wakya (MC) greatly affect the appearance of the event as a whole then ugra wakya (MC) profession can not be done by indiscriminate people. Thus, the ugra wakya (MC) profession is one of the promising professions, especially the opportunity to improve the degree of life for the perpetrators.

Ugra wakya (MC) as an oral art requires the devotees to train more vocals than their ability to process language and body language in delivering an event. Appearance is also a requirement that must be taken into account if you want to 
become ugra wakya (MC) who quickly accepted in the hearts of the audience.

\section{REFERENCES}

Aryati, Lies. 2008. Panduan untuk Menjadi MC Profesional. Jakarta: Penerbit PT Gramedia Pustaka Utama.

Bali Post edisi Rabu tanggal 24 Agustus 2016 hlm.2. "Badung Rekrut Ratusan Tenaga Pengajar".

Keraf, Gorys. 1984. Komposisi (Sebuah Pengantar Kemahiran Bahasa). Flores: Penerbit Nusa Indah.

Larry King dan Bill Gilbert. 2005. Seni Berbicara, kepada Siapa Saja, Kapan Saja, di Mana Saja. Jakarta: Penerbit PT Gramedia Pustaka Utama.

Nida, Eugene A. 1957. Learning a Foreign Language. Michigan, Ann Arbor: Cushing-Molloy, Inc.

Oka, I Gusti Ngurah dan Basuki. 1990. Retorika Kiat Bertutur. Malang: Yayasan Asih Asah Asuh Malang (Y A 3 Malang).

Suardiana, I Wayan. 2016. "Kunci Wasiat Kebudayaan: Membuka Peradaban dengan Aksara Bali" Paper dibawakan dalam Seminar Bulanan Seri Sastra dan Budaya, Fakultas Ilmu Budaya, Universitas Udayana yang diselenggarakan pada hari Jumat, 23 Desember 2016 di Aula FIB Unud.

Sugono, Dendy. 2005. Pedoman Umum Pembentukan Istilah. Jakarta: Pusat Bahasa Departemen Pendidikan Nasional.

Sukirno. 2010. Belajar Cepat Menulis Kreatif Berbasis Kuantum untuk yang Ingin Cepat Terampil Menulis Kreatif. Yogyakarta: Pustaka Pelajar.

Tarigan, Henry Guntur. 1986. Menulis Sebagai Suatu Keterampilan Berbahasa. Bandung: Angkasa. 